\title{
Food resources and population pattern in Apis mellifera hives used for apple pollination
}

\author{
Lucas de Almeida Bizotto(1), Regis Sivori Silva dos Santos ${ }^{(2)}$ and Mari Ines Carissimi Boff(1)
}

\begin{abstract}
(1)Universidade do Estado de Santa Catarina, Centro de Ciências Agroveterinárias, Avenida Luiz de Camões, no 2.090, Conta Dinheiro, CEP 88520-000 Lages, SC, Brazil. E-mail: bizottolucas@yahoo.com.br, mari.boff@udesc.br (2)Embrapa Uva e Vinho, Estação Experimental de Fruticultura de Clima Temperado, BR 285, Km 115, CEP 95200-000 Vacaria, RS, Brazil. E-mail: regis.sivori@embrapa.br
\end{abstract}

\begin{abstract}
The objective of this work was to evaluate the variations in the stored food resources and in the number of immature bees in Apis mellifera hives used for apple (Malus domestica) pollination. The study was conducted in the municipality of Vacaria, in the state of Rio Grande do Sul, Brazil, with 40 hives, over two consecutive harvests. The evaluations were done in the hive brood frames before, during, and 45 days after a pollination period, by interpreting photographic field records. Before being transported to the orchards, the bees foraged primarily in areas with native forest or canola (Brassica napus) crop, in 2014/2015, and with native forest or eucalyptus (Eucalyptus sp.) reforestation, in 2015/2016. In both harvests, the percentage of food resources (honey and pollen) stored in the hives reduced significantly between the pre- and post-pollination periods, but there was no significant difference between the pollination and post-pollination periods. The greatest reduction in the storage of these resources was observed in the hives from the canola crop, which had a large supply of floral resources compared with the apple orchards. The hives most susceptible to population variations within the apple orchards are those from the canola crop, whereas those from areas with a lower food supply (forest and eucalyptus) show population gains in the apple orchards.
\end{abstract}

Index terms: Brassica napus, Eucalyptus, Malus domestica, floral resource, pollination.

\section{Recursos alimentares e padrão populacional em colmeias de Apis mellifera utilizadas para polinização de macieiras}

Resumo - O objetivo deste trabalho foi avaliar as variações nos recursos alimentares armazenados e no número de imaturos em colmeias de Apis mellifera utilizadas para polinização de pomares de macieiras (Malus domestica). O estudo foi realizado no Município de Vacaria, RS, com 40 colmeias, em duas safras consecutivas. As avaliações foram feitas nos caixilhos das colmeias antes, durante e 45 dias após serviço de polinização, por meio da interpretação de registros fotográficos realizados em campo. Antes do transporte para os pomares, as abelhas forrageavam primariamente em áreas com floresta nativa ou lavoura de canola (Brassica napus), em 2014/2015, e com floresta nativa ou reflorestamento de eucalipto (Eucalyptus sp.), em 2015/2016. Em ambas as safras, a percentagem de recursos alimentares (mel e pólen) armazenados na colmeia diminuiu significativamente entre os períodos de pré e pós-polinização, mas não houve diferenças significativas entre os períodos de polinização e pós-polinização. A maior redução no armazenamento desses recursos ocorreu em colmeias provenientes da lavoura de canola, a qual apresentava grande oferta de recursos florais comparada aos pomares de maçã. As colmeias mais suscetíveis a variações populacionais são as provenientes da lavoura de canola, enquanto aquelas de áreas com menor suprimento de alimento (floresta $\mathrm{e}$ eucalipto) apresentam ganhos populacionais nos pomares de maçã.

Termos para indexação: Brassica napus, Eucalyptus, Malus domestica, recurso floral, polinização.

\section{Introduction}

In less than 40 years, Brazil has become selfsufficient in the production of apples and has started exporting a part of its production (Fioravanço, 2009; Bittencourt et al., 2011). However, in order to maintain the achieved economic status, several production factors of this crop require further investigation, including the management of bee hives used for pollination services.

Apple (Malus domestica Borkh) trees are crosspollinated (Petri et al., 2011; Garratt et al., 2014; Sheffield, 2014) and, therefore, their fruit production depends heavily on the presence of pollinators, especially of honeybees. Honeybees are the most important pollination agent in this crop, accounting 
for approximately $97 \%$ of the pollinators that visit its flowers; for this reason, A. mellifera is widely used in apple pollination in Brazil (Santos et al., 2013). Moreover, A. mellifera swarms are easy to handle, the hives carry high populations, the swarms can be easily transferred from the apiaries to the orchards, and the pollination of apple trees is highly efficient (Freitas \& Alves, 2008). Nonetheless, there are aspects that still need to be addressed to better manage the swarms in the orchards, particularly with respect to hive maintenance for different bee populations.

Knowledge regarding the availability of food resources (pollen and honey) in hives and nursery areas before, during, and after pollination is fundamental for the sustainability of the swarms. The storage of protein- and energy-rich food resources (pollen and honey, respectively) is crucial to cope with periods of scarcity, being necessary for bee survival, for example, during the winter in Southern Brazil (Castagnino et al., 2006). Bees that survive this period are responsible for finding new floral resources in early spring and play a key role in the population dynamics of the beehive.

Population growth is greater in hives with greater availability of energy resources (McNally \& Schneider, 1992; Silva \& Freitas, 2004). Vidal et al. (2008) reported that the queen lays more eggs in periods with greater availability of food, pollen, and nectar (Costa et al., 2007), particularly of nectar. The reproductive stimulation of the queens allows increasing the population of the hive and, consequently, strengthening the population - strong hives pollinate better (Pegoraro et al., 2013) and tend to resist periods of stress.

Few known studies, however, have evaluated the internal dynamics of hives of $A$. mellifera used in apple pollination. The information provided by this kind of work may contribute to the management of hives and to the increase in the sustainability of the swarms used in pollination.

The objective of this work was to evaluate the variations in the stored food resources and in the number of immature bees in A. mellifera hives used for apple pollination.

\section{Materials and Methods}

The study was conducted in commercial apple orchards with the Royal Gala and Fuji Suprema cultivars, in the municipality of Vacaria, in the state of Rio Grande do Sul, Brazil, in two harvests:
2014/2015, from September 9, 2014, to December 10, 2014 , at $28^{\circ} 25^{\prime} 40.5^{\prime \prime} \mathrm{S}, 050^{\circ} 53^{\prime} 35.9^{\prime \prime} \mathrm{W}$; and $2015 / 2016$, from September 2, 2015, to December 15, 2015, at $28^{\circ} 36^{\prime} 45.55^{\prime \prime} \mathrm{S}, 50^{\circ} 53^{\prime} 31.96^{\prime \prime} \mathrm{W}$. In both evaluation periods, two groups of 20 hives (Langstroth), containing 12 brood frames each, were formed. Before being transported to the apple orchards, the bees foraged primarily in areas with native forest or canola (Brassica napus L.) crop in the 2014/2015 harvest; and in areas with forest or eucalyptus (Eucalyptus sp.) reforestation, in the $2015 / 2016$ harvest. In the 2014/2015 harvest, natural swarms occurred in three hives of the group from the canola crop. However, no natural swarms were observed in the other evaluated beehives; therefore, the swarming hives were excluded from the analysis.

The study initially included 40 hives, which were labelled with numbers indicating their respective beehive group: native forest, canola crop, or eucalyptus reforestation. Three evaluations were performed at different stages: the first, at the beginning of the pollination period, before moving the hives to the apple orchards; the second, at the end of the pollination period, which lasted for 45 days, before moving the hives from the orchards; and the third, 45 days after moving the hives from the orchard, back to their sites of origin.

The evaluations consisted of acquiring field images from both sides of the brood frames of each hive. For image standardization, a template with a frame containing nylon threads inside was used, and the threads formed 12 squares measuring $7 \times 10 \mathrm{~cm}$ each. The template was placed $80 \mathrm{~cm}$ from the brood frames, and the images were taken using a digital camera. Each image was analyzed for the following parameters: percentage of the brood frame with stored food resources (pollen and honey), percentage with open brood (larvae), and percentage with capped brood (pupae); all percentages were calculated considering the comb area in each evaluated hive.

Data was analyzed for normality using the ShapiroWilk test, and homoscedasticity was analyzed using the Hartley-Bartlett test. Means were compared by Tukey's test, at 5\% probability, using the SASM-Agri software (Canteri et al., 2001).

\section{Results and Discussion}

In the 2014/2015 harvest, there was a significant reduction in the amount of pollen regardless of the sites 
of origin of the hives. This reduction, however, was more pronounced in the hives from the canola crop: the pollen area reduced approximately $60 \%$ at the end of the pollination period (Figure $1 \mathrm{~A}$ ). Despite this, the
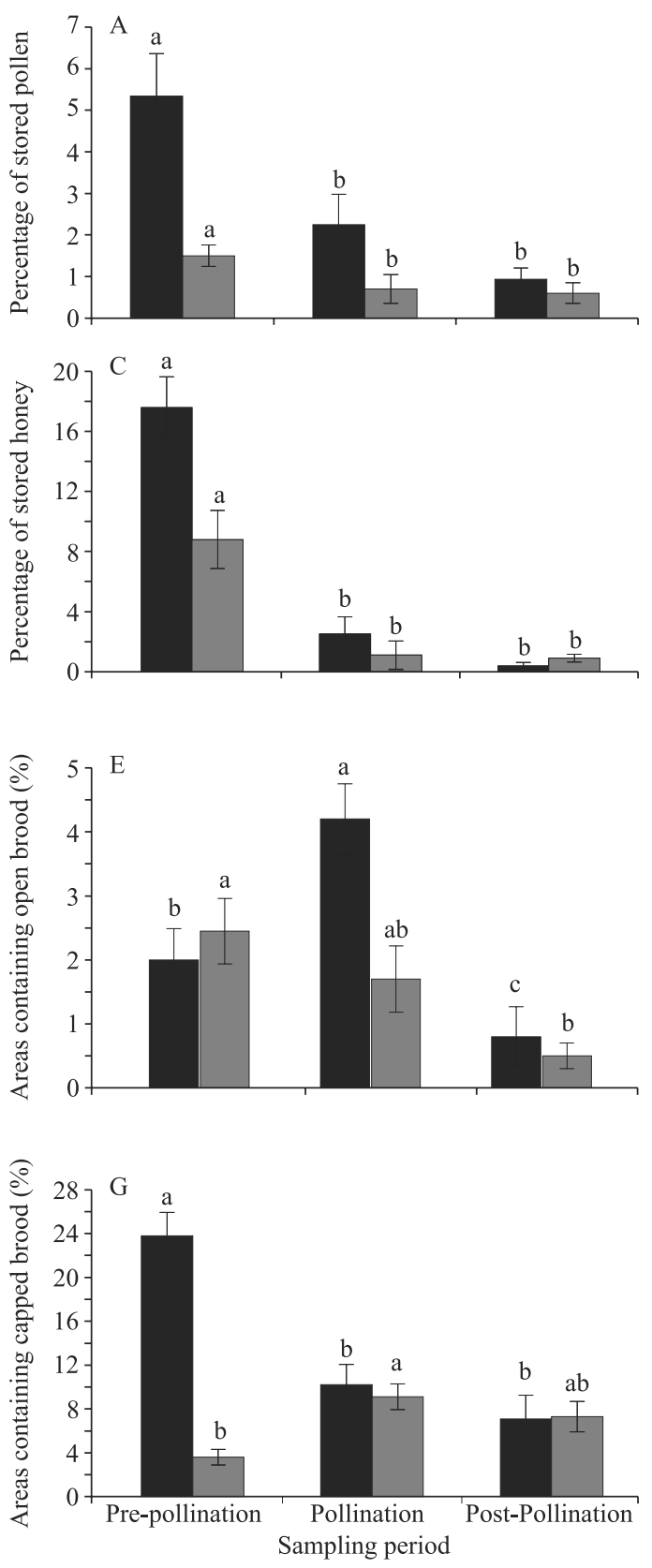

Canola production areas stored pollen did not differ significantly between the hives from the canola crop and the native forest.

In the 2015/2016 harvest, the area of stored pollen was statistically the same between the sites of origin of
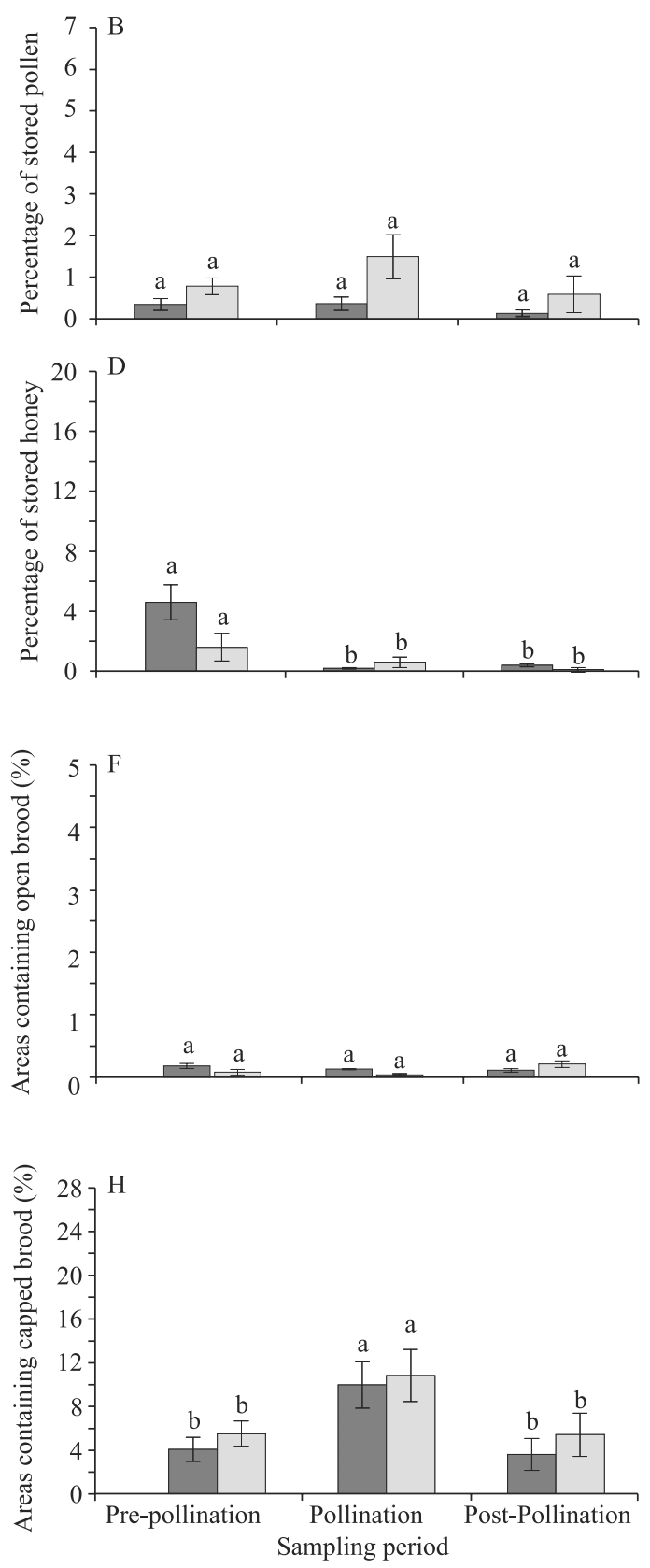

$\square$ Forest areas $\square$ Eucalyptus forest

Figure 1. Percentage of brood frames containing stored pollen, stored honey, open brood, and capped brood in the 2014/2015 (A, C, E, and G, respectively) and in the 2015/2016 (B, D, F, and H) harvests, in Apis mellifera hives used for apple (Malus domestica) pollination. Means followed by equal letters do not differ by Tukey's test, at $5 \%$ probability. 
the hive (Figure 1 B) - forest or eucalyptus reforestation - and between the evaluation periods - pre-pollination, pollination, and post-pollination.

In both harvests, there was a significant reduction in the percentage of stored honey between the prepollination and pollination periods, but no significant difference was observed between the pollination and post-pollination periods (Figure $1 \mathrm{C}$ and D). The highest reductions of 85.0 and $95.5 \%$ in honey storage occurred, respectively, in the hives from the canola crop and from the area with eucalyptus reforestation.

Canola is an oleaginous plant and a good source of floral resources for bee populations during resource scarcity periods (Witter \& Tirelli, 2014). Canola bloomed at the end of winter in the 2014/2015 harvest, and provided sufficient floral and food resources for the maintenance and expansion of the bee populations. In this harvest, the percentage of the brood frames occupied with food resources (pollen and honey) in the pre-pollination period was significantly higher in the canola crop than in the area with native forest or with eucalyptus reforestation (Figure 1). The reduction in the brood frame percentage occupied with food resources during the apple pollination period indicates that the floral resources available were not enough and that food reserves were used for population maintenance. This can be attributed to the fact that, during the pollination period, the honeybees had to forage in isolated areas, with low plant diversity, i.e., the apple orchards. Therefore, the flowering of apple trees cannot maintain the food reserves inside the hives, particularly in those from the canola crop, which has abundant floral resources. The failure to recover the food reserves (pollen and honey) 45 days after the pollination period is an indicative that the transport and relocation of the hives for foraging negatively affected the performance of the honeybees.

The availability of floral resources and the collecting behavior of the honeybees are affected by climatic conditions (Funari et al., 2003; Pereira et al., 2013; Fonseca \& Kerr, 2006). In the two evaluated harvests, intense rainfall occurred during the flowering of the apple trees. According to data gathered for the region, there was rainfall in $40-45 \%$ of the bloom days in the orchards, and cumulative rainfall was $318 \mathrm{~mm}$ in 2014/2015 and $397 \mathrm{~mm}$ in 2015/2016.

In the 2015/2016 harvest, the El Niño phenomenon increased rainfall in Southern Brazil during the flowering period. According to Orth et al. (2016), this phenomenon limits beekeeping as a whole and affects pollination in apple orchards. The high precipitation conditions in the El Niño period (2015/2016 harvest) may partly explain the low percentage of pollen and honey reserves in the hives in the pre-pollination period, as well as the further reduction in the pollination and post-pollination periods. Food reserves in these periods were below $2 \%$, lower than the level of $4 \%$ reported by Costa et al. (2007). Funari et al. (2003) also found that intense rainfall during the flowering period negatively affected the availability of nectar and pollen and, consequently, the production of honey, since the bees do not leave the hives under these conditions.

The low levels of food resources observed in the hives are a cause for concern because debilitated hives may die (Pegoraro et al., 2013). McNally \& Schneider (1992) observed that bees from weak hives tend to disappear if there is no supply of food resources.

As to the population pattern, the percentage of open brood (larvae) in the hives from the canola crop was significantly affected by the evaluated periods in the 2014/2015 harvest (Figure 1 E). There was also a significant increase in the areas containing larvae, between the pre-pollination and pollination periods, followed by a subsequent decrease in the post-pollination period. However, in the hives from the native forest, the percentage of open brood was not significantly affected by the pollination periods. In the 2015/2016 harvest, no significant differences in the percentage of brood frames occupied by larvae were observed between the assessed periods (Figure $1 \mathrm{~F}$ ).

The percentage of capped brood in the hives from the canola crop decreased significantly between the prepollination, pollination, and post-pollination periods, but no significant difference was observed between the pollination and post-pollination periods (Figure $1 \mathrm{G})$. However, in the hives from the native forest, a significant increase in this parameter was verified between pre-pollination and the two other periods. The results of the 2015/2016 harvest were similar to those of 2014/2015, with a significant increase in the percentage of capped brood during the pollination period and a decrease 45 days after the hives were removed from the orchards (Figure $1 \mathrm{H}$ ).

These results indicate that the canola crop was the most susceptible to population variations due to the pollination period in the apple orchards. In 
contrast, beehives located in areas with lower flower resources (forest and eucalyptus reforestation areas) showed gains during this period. This result reveals that apple orchards can be an important source of food resources, but this is related to the availability of food before the pollination period. The bee population of the hives from the canola crop was reorganized through swarming, which was directly associated with the collection of resources and the dynamics of the bee population. Weaker hives, however, from the areas with lower floral resources, were not able to cast swarms and seemed to be stimulated by the greater food availability in the apple orchards.

The greater availability of energy-rich food (nectar) is positively correlated with the increase of egg laying in the hives and, consequently, with the increase in the percentage of rearing areas in the brood frames (Funari et al., 2003; Schafaschek et al., 2008; Silva et al., 2010). Offspring abundance is associated with the type of resources (Mattila et al., 2001), and reductions in the brood rearing areas occur under conditions of limited food supply (Costa et al., 2007; Vidal et al., 2008; Genersch et al., 2010). The egg laying behaviour of the queen, in turn, depends on several factors, including the availability of areas in the brood frame and the balance between food resources and adult bees in the hives (Silva \& Freitas, 2004).

The greater offspring in the hives from eucalyptus reforestation, compared with those from the native forest, is due to the greater availability of resources for swarming in the reforested area (Rusig et al., 2002). According to Bizotto \& Santos (2015), the main food resource collected by A. mellifera during the flowering period of apple trees was nectar, which might explain the population growth observed in the hives from the native forest and the eucalyptus areas.

\section{Conclusions}

1. The pollination period in apple (Malus domestica) orchards reduces the storage of food resources (honey and pollen) in the hives, mainly if the pre-pollination period is conducted in an area with a large supply of floral resources, such as the canola (Brassica napus) crop.

2. The hives from the canola crop are the most susceptible to population variations within the apple orchards, whereas those from areas with a lower floral supply (forest and eucalyptus) can have population gains in the apple orchards.

3. Apple orchards can be an important source of food resources for the hives, but this depends on the availability of food before the pollination period.

\section{Acknowledgments}

To Coordenação de Aperfeiçoamento de Pessoal de Nível Superior (Capes), for scholarship granted; and to Conselho Nacional de Desenvolvimento Científico e Tecnológico (CNPq), for an award for excellence in research (process number 304081/2015-9).

\section{References}

BITTENCOURT, C.C.; MATTEI, L.F.; SANT'ANNA, P.R. de; LONGO, O.C.; BARONE, F.M. Cadeia produtiva da maçã em Santa Catarina: competitividade segundo produção e packing house. Revista de Administração Pública, v.45, p.1199-1222, 2011. DOI: 10.1590/S0034-76122011000400013.

BIZOTTO, L. de A.; SANTOS, R.S.S. dos. Dinâmica de voo e coleta de recursos por Apis mellifera em pomar de macieira. Enciclopédia Biosfera, v.11, p.3499-3506, 2015.

CANTERI, M.G.; ALTHAUS, R.A.; VIRGENS FILHO, J.S. da; GIGLIOTI, E.A.; GODOY, C.V. SASM-Agri: sistema para análise e separação de médias em experimentos agrícolas pelos métodos Scott-Knott, Tukey e Duncan. Revista Brasileira de Agrocomputação, v.1, p.18-24. 2001.

CASTAGNiNO, G.L.; ARBOITTE, M.Z.; LENGLER, S.; GARCIA, G.G.; MENEZES, L.F.G. de. Desenvolvimento de núcleos de Apis mellifera alimentados com suplemento aminoácido vitamínico, Promotor L ${ }^{\circledR}$. Ciência Rural, v.36, p.685-688, 2006. DOI: $10.1590 / \mathrm{S} 0103-84782006000200054$.

COSTA, F.M.; MIRANDA, S.B. de; TOLEDO, V. de A.A. de; RUVOLO-TAKASUSUKI, M.C.C.; CHIARI, W.C.; HASHIMOTO, J.H. Desenvolvimento de colônias de abelhas Apis mellifera africanizadas na região de Maringá, Estado do Paraná. Acta Scientiarum. Animal Sciences, v.29, p.101-108, 2007. DOI: 10.4025/actascianimsci.v29i1.265.

FIORAVANÇO, J.C. Maçã Brasileira: da importação à autosuficiência e exportação - a tecnologia como fator determinante. Informações Econômicas, v.39, p.56-67, 2009.

FONSECA, V.M. de O.; KERR, W.E. Influência da troca de rainhas entre colônias de abelhas africanizadas na produção de pólen. Bioscience Journal, v.22, p.107-118, 2006.

FREITAS, B.M; ALVES, J.E. Efeito do número de visitas florais da abelha melífera (Apis mellifera L.) na polinização da goiabeira (Psidium guajava L.) cv. Paluma. Revista Ciência Agronômica, v.39, p.148-154, 2008.

FUNARI, S.R.C.; ROCHA, H.C.; SFORCIN, J.M.; CURI, P.R.; FUNARI, A.R.M.; ORSI, R. de O. Efeitos da coleta de pólen no 
desenvolvimento de colônias e na composição bromatológica de pupas de Apis mellifera L. Archivos Latinoamericanos de Producción Animal, v.11, p.80-86, 2003.

GARRATT, M.P.D.; BREEZE, T.D.; JENNER, N.; POLCE, C.; BIESMEIJER, J.C.; POTTS, S.G. Avoiding a bad apple: insect pollination enhances fruit quality and economic value. Agriculture, Ecosystems and Environment, v.184, p.34-40, 2014. DOI: 10.1016/j.agee.2013.10.032.

GENERSCH, E.; OHE, W. von der; KAATZ, H.; SCHROEDER, A.; OTTEN, C.; BÜCHLER, R.; BERG, S.; RITTER, W.; MÜHLEN, W.; GISDER, S.; MEIXNER, M.; LIEBIG, G.; ROSENKRANZ, P. The German bee monitoring project: a long term study to understand periodically high winter losses of honey bee colonies. Apidologie, v.41, p.332-352, 2010. DOI: 10.1051/ apido/2010014.

MATTILA, H.R.; HARRIS, J.L.; OTIS, G.W. Timing of production of winter bees in honey bee (Apis mellifera) colonies. Insectes Sociaux, v.48, p.88-93, 2001. DOI: 10.1007/PL00001764.

MCNALLY, L.C.; SCHNEIDER, S.S. Seasonal cycles of growth, development and movement of the African honey bee, Apis mellifera scutellata, in Africa. Insectes Sociaux, v.39, p.167-179, 1992.

ORTH, A.I.; VIEIRA, H.J.; RICCE, W.S.; RODRIGUES, M.L.G. As chuvas intensas do El Niño de 2015 e a frustração na apicultura catarinense. Informativo Zum Zum, v.50, p.26-28, 2016.

PEGORARO, A.; NUNES, F.L.; PEREIRA, F.F.; TEIXEIRA, R.A.; KRUGER, E.; SERMANN, K.C. Perdas de colônias de Apis mellifera L. no inverno suplementadas com alimentação artificial com pólen e favos de mel. Revista Agrarian, v.6, p.67-74, 2013.

PEREIRA, D.S.; PAIVA, C. da S.; BARBOSA, G.R.; MARACAJÁ, P.B.; LIMA, C.J. de. Produção de rainhas (Apis mellifera L.), e taxa de fecundação natural em quatro municípios do nordeste brasileiro. Revista Verde, v.8, p.9-16, 2013.

PETRI, J.L.; LEITE, G.B.; COUTO, M.; FRANCESCATTO, P. Avanços na cultura da macieira no Brasil. Revista Brasileira de Fruticultura, v.33, p.48-56, 2011. Volume especial.
RUSIG, A.; NOGUEIRA-COUTO, R.H.; COUTO, L.A. Tela excluidora de rainha na produção de mel e na longevidade das operárias em colmeias de Apis mellifera. Ciência Rural, v.32, p.329-334, 2002. DOI: 10.1590/S0103-84782002000200024.

SANTOS, R.S.S. dos; SEBBEN, V.H.; WOLFF, L.F. Visita floral de Apis mellifera L. em diferentes clones de cultivares de maçã Gala e Fuji e sua relação com variáveis meteorológicas em Vacaria, RS, Brasil. Revista de la Facultad de Agronomía, v.112, p.114-122, 2013.

SCHAFASCHEK, T.P.; PADILHA, M.T.S.; SANTOS, I.I. dos; PADILHA, J.C.F.; BRAGA, F.E. Efeito da suplementação alimentar sobre as características produtivas e reprodutivas de Apis mellifera Linnaeus, 1758. Biotemas, v.21, p.99-104, 2008.

SHEFFIELD, C.S. Pollination, seed set and fruit quality in apple: studies with Osmia lignaria (Hymenoptera: Megachilidae) in the Annapolis Valley, Nova Scotia, Canada. Journal of Pollination Ecology, v.12, p.120-128, 2014.

SILVA, D.F. da; ARAÚJO, I.G.; WELTER, J.H.; WAGNER, R.B.; MENEZES, L.F.G. de; ARBOITTE, M.Z. Desenvolvimento e produção de pólen em colmeias de Apis mellifera L. africanizadas mantidas em cultura de girassol. Revista Agrarian, v.3, p.147$151,2010$.

SILVA, R.H.D. da; FREITAS, B.M. Produção e desenvolvimento de colônias de abelhas africanizadas (Apis mellifera $\mathrm{L}$.) a partir de diferentes áreas e idades de cria. Ciência Rural, v.34, p.545-549, 2004.

VIDAL, M.G.; SANTANA, N. da S.; VIDAL, D. Flora apícola e manejo de apiários na região do recôncavo sul da Bahia. Revista Acadêmica: Ciências Agrárias e Ambientais, v.6, p.503-509, 2008.

WITTER, S.; TIRELLI, F. Polinizadores nativos presentes em lavouras de canola no Rio Grande do Sul. In: WITTER, S.; NUNES-SILVA, P.; BLOCHTEIN, B. (Org.). Abelhas na polinização da canola: benefícios ambientais e econômicos. Porto Alegre: EDIPUCRS, 2014. p.29-36. 